\title{
Uma análise espacial-comparativa da dinâmica da atividade silvícola na Oitava Região do Chile: 1997-2007
}

\section{A spatial-comparative analysis of the dinamic of the forest activity in Eighth Region of Chile: 1997-2007}

Junior Ruiz-Garcia*

\begin{abstract}
The goal of this paper is to undertake a spatial and comparative analysis of the changes in the forest production in the Eighth Chilean Region based on a Geographic Information System (GIS). The forest production is concentrated in the Seventh, Eighth, and Ninth Regions, which account for $76.8 \%$ of the planted area. The analysis will be based on spatialized information of the forest production for the Eighth region published in the Agricultural Census in 1997 and 2007. From 1997 to 2007 the forest area presented a strong expansion. This dynamic can bring many changes in the economy and society, and natural environments.
\end{abstract}

Keywords: forestry, forest plantations, Geographic Information System - GIS, Chile.

\section{Resumo}

O objetivo deste trabalho é empreender uma análise espacial-comparativa das transformaçôes na atividade silvícola da Oitava Regiáo Chilena com auxílio do Sistema de Informaçóes Geográficas (sIG). A silvicultura encontra-se concentrada na Sétima, Oitava e Nona Regióes Chilenas, que respondem por $76,8 \%$ da superfície plantada. A análise será realizada com base nas informações espacializadas do cultivo florestal da Oitava Região publicadas nos Censos Agropecuários de 1997 e 2007. No período entre 1997-2007 a área silvícola apresentou forte expansão. Essa dinâmica pode trazer inúmeras transformações na economia e sociedade, além de alterar os ambientes naturais.

Palavras-chaves: silvicultura, plantaçôes florestais, Sistema de Informação Geográfica - sIG, Chile.

\footnotetext{
* Universidade Federal do Paraná. Correo-e: jrgarcia1989@gmail.com
} 


\section{Introduçáo}

Nos últimos anos foi possível verificar uma forte expansão da indústria de celulose e papel chilena, particularmente na Regiáo do Bío Bío (Oitava Regiáo). Associado à expansão da indústria celulósica e papeleira temse o setor silvicultor, caracterizado pelo cultivo das espécies pinos e eucaliptos, que apresentou desde a década de 1970 uma forte expansão.

A dinâmica apresentada por ambos os setores (industrial e silvicultor) levou a Oitava Regiāo a se tornar a principal regiāo chilena em termos de área cultivada com espécies florestais de alto rendimento (florestas plantadas) e a maior produtora de produtos madeireiros. A produçáo pode ser caracterizada por produtos que são destinados ao mercado externo (in natura e/ou com algum grau de processamento) e ao mercado interno (serralherias, indústria de chapas de aglomerados e de móveis e também para a produção de celulose e papel).

A atividade silvícola é uma importante fonte de divisas internacionais para o Chile, assim como na geração de emprego e renda, em especial na Oitava Região. Desta maneira, o objetivo principal deste trabalho é analisar a dinâmica do setor silvicultor instalado na Regiáo do Bío Bío.

O desenvolvimento da análise empreendida neste trabalho contará com o auxílio das técnicas dispostas pelo Sistema de Informação Geográfica - SIG, as quais serão utilizadas para a espacialização das informaçóes censitárias disponibilizadas pelo Instituto Nacional de Estadísticas - INE do Chile.

O trabalho está organizado em três seçóes, além desta breve introdução e das consideraçóes finais. Na primeira são descritos os materiais utilizados tais como software e tipos e fontes das informaçóes, além as técnicas utilizadas para tratamento das informaçôes. Na seguinte, faz-se uma apresentação geral da Oitava Regiáo, em que são apresentados alguns aspectos socioeconômicos. $\mathrm{Na}$ terceira seção será realizada a análise do setor silvícola chileno, para o qual se direciona a investigação da Oitava Região. Finalmente, apresentam-se as consideraçóes finais sobre os resultados dessa investigação.

\section{Materiais e técnicas}

O desenvolvimento deste trabalho, em termos dos materiais -informaçóes e recursos computacionais- e técnicas, consistiu basicamente no uso de dados geográficos (mapas digitais no formato shapefile - estrutura de dados vetorial) e censitários e das técnicas dispostas pelo instrumental conhecido como Sistema de Informação Geográfica - sig. 
Os dados geográficos foram disponibilizados na Internet pela Oficina de Estudos y Politicas Agrárias - ODEPA, por meio do Sistema de Consulta Estadistico Territorial - i-CET. No que se refere aos dados geográficos (mapas digitais em formato: shapefile ou vetorial), este estudo utilizou apenas um mapa digital que apresenta as delimitações político-administrativas das comunas (semelhante aos municípios ou cidades) da Oitava Região Chilena. Essa cobertura shapefile está na escala 1:50.000 e projeção geográfica UTM (Universal Transverse Mercator) Datum wgs84-I9s. Por fim, a shapefile apresenta a divisão político-administrativa e alguns atributos descritivos (área, perímetro etc.), sendo a unidade territorial mínima representada pela comuna (i-CET, 2009a).

As informaçôes alfanuméricas espacializadas foram levantadas pelo Censo Agropecuário Chileno para o período 1997 e 2007, o qual é realizado pelo Instituto Nacional de Estadística Chileno - INE a cada 10 anos. Este trabalho fez uso das informaçóes censitárias disponíveis na página de Internet do referido instituto e do Sistema de Consulta Estadístico Territorial Chileno - i-CET (vinculado à Oficina de Estudos y Politicas Agrárias - ODEPA) para o período: 1997-2007 (INE, 1997 e 2007 e i-CET, 2009a, 2009b e 2009c).

As informações geográficas foram tratadas com o Software ArcGis 9.3, compreendendo a especialização (incorporação ou integração) das informaçôes censitárias às coberturas digitais, a criação de coberturas digitais de limites regionais e temáticas.

\section{Oitava regiáo chilena - características socioeconômicas}

O Chile está organizado, em termos da divisão político-administrativa, em xv Regiôes (semelhante à organização de Estados Subnacionais), inclusa a Regiáo Metropolitana de Santiago - RMS, compostas por 52 províncias (sub-regióes - unidades intermediárias) e por 346 comunas (semelhante à unidade municipal ou cidades) (mapa I) (i-CET, 2009a).

A Oitava Região tem uma superfície de aproximadamente 37,000 $\mathrm{km}^{2}$, localizada na regiáo central do Chile (mapa I). Segundo dados do Censo Demográfico de 2002, essa regiāo abrigava cerca 1'9,000,000 de habitantes, resultando em uma densidade demográfica da ordem de 50,4 hab. $/ \mathrm{km}^{2}$. Ainda, a populaçáo estava distribuída da seguinte maneira: $60,2 \%$ no meio urbano (taxa de urbanização) e 39,8\% no meio rural (INE, 2002). Observa-se, que ainda existe uma importante parcela da população vinculada à atividade agrícola, e consequentemente a silvicultura.

Cabe enfatizar que a Oitava Regiáo, conjuntamente com a Nona, abriga a importante Bacia Hidrográfica do Rio Bio Bío. Cerca de $70 \%$ da bacia encontra-se localizada na Oitava Região $\left(17,000 \mathrm{~km}^{2}\right.$ ou 1'700,000 


\section{Mapa I \\ Localizaçáo da Oitava Regiáo no Território Chileno e suas Comunas}

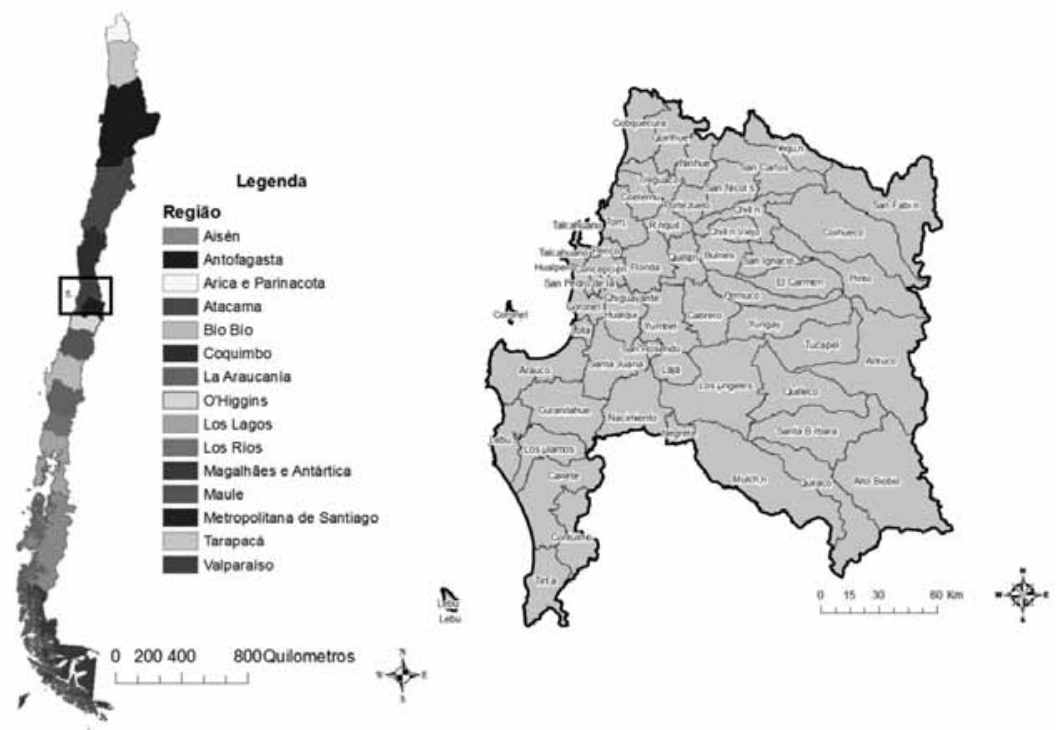

Fonte: Elaborado com base em i-CET, 2009a.

milhão de hectares, que corresponde a $45 \%$ do território regional). Neste sentido, a atividade silvícola empreendida pode ter importantes impactos sobre os ecossistemas, especialmente sobre a dinâmica hidrológica (Parra et al., 2004).

$\mathrm{Na}$ regiáo um importante aspecto físico merece ser destacado, referese ao predomínio de solos considerados como frágeis nas áreas destinadas ao cultivo florestal (mapa II). Além disso, essas áreas são caracterizadas pela grande inclinação ou pendência - declividade do terreno (mapa III). Esse conjunto de características pode amplificar os impactos ambientais e sociais associadas à silvicultura.

Em termos econômicos, a Oitava Região contribuiu entre 2003-2008 em média com $9 \%$ do Produto Interno Bruto Chileno - PIB, colocandoa como a segunda regiáo em importância econômica, perdendo somente para a Região Metropolitana de Santiago - RMs, que contribui em média com 43\%. Em 2008, estima-se que o pIB nacional (em cifras preliminares) foi da ordem de M.M\$ 64.954.930 (a preço constante de 2003, em mil milhôes de pesos chilenos), (Banco Central, 2010), o que equivale em torno de US\$163'700'000,000,000 segundo dados do World Bank (2011).

Em termos sociais, o principal indicador utilizado é o Índice de Desenvolvimento Humano - IDH, publicado pelo PNUD - Programa das 


\section{Mapa II}

Características dos solos da Oitava Região

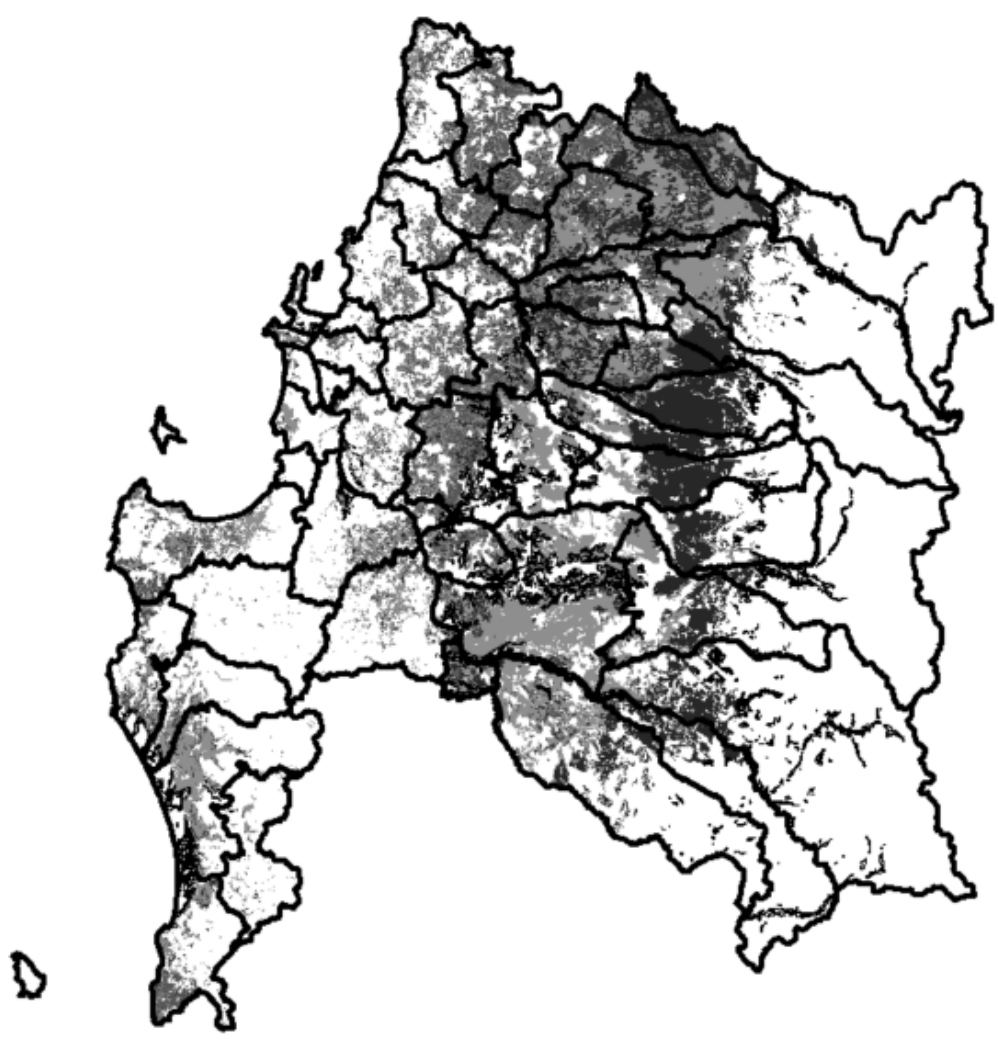

\section{Legenda}

$\square$ Limites Comunal

Características do Solo

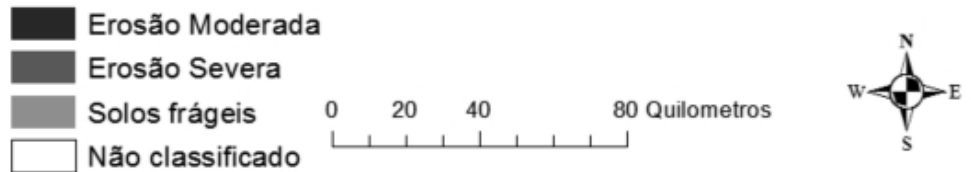

Fonte: Elaborado com base em Conaf (2008a). 


\section{Mapa III}

Pendentes (inclinaçáo percentual - \%) do solo da Oitava Regiáo

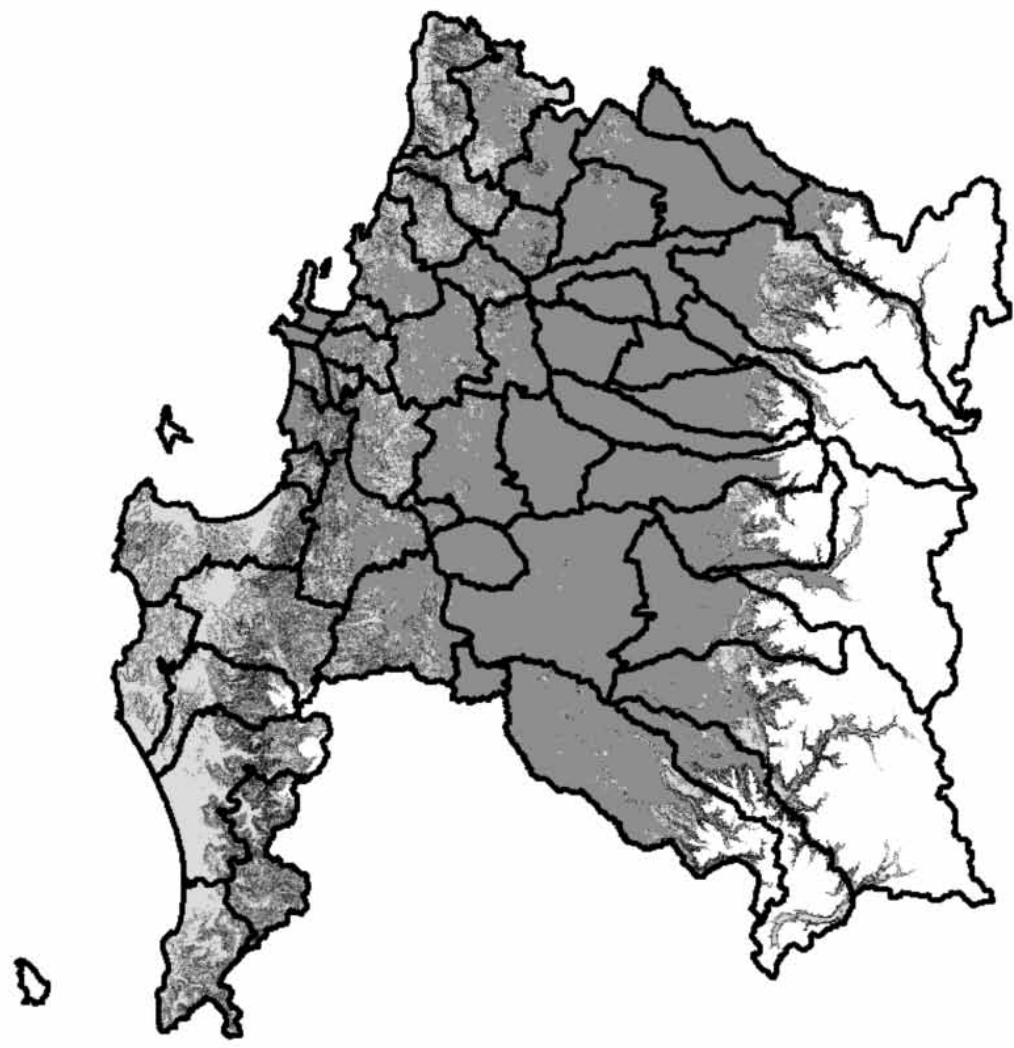

\section{Legenda}

$\square$ Limites Comunal

Pendente - Inclinação do Terreno

$\square$ Não classificado
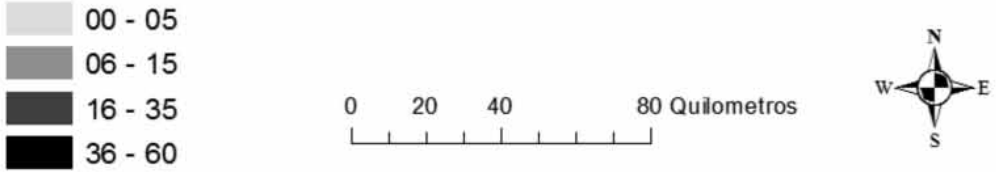

Fonte: Elaborado com base em Conaf (2008a). 
Naçôes Unidas para o Desenvolvimento. Com base no IDH é possível observar que a Oitava Região mesmo ocupando a segunda posição em importância econômica do Chile, apresenta um dos piores IDH registrados no país (PNUd, 2006) (mapa IV).

Segundo os últimos dados divulgados em âmbito regional e comunal pelo PNUD referentes a 2003, o IDH da Oitava Região registrou o décimo pior no ranking nacional (mesma posição registrada em 1994), um índice de 0,686 , representa médio desenvolvimento humano. O IDH chileno verificado no período era de 0,725 , colocando-o na categoria de alto desenvolvimento humano ${ }^{1}$. A comuna de Trehuaco apresentou o pior IDH $(0,562)$, e o maior IDH foi registrado em San Pedro de la Paz $(0,787)$. É possível observar no mapa IV que há um conjunto de comunas próximas ao litoral com IDH entre 0,562 e 0,611 (PNUD, 2006) (mapa IV), que em sua maioria apresentaram forte avanço no cultivo florestal (mapa v).

A situação apresentada pelo IDH reflete as desigualdades socioeconômicas verificadas entre as comunas (tabela I). Independente da importância da atividade silvícola e da indústria de celulose e papel, os indicadores sociais. Por exemplo, a Comuna de Laja, embora abrigue uma importante unidade produtora da celulosa e possua extensas plantaçóes florestais, a taxa de pobreza no período $1994-2003$ saltou de $26,6 \%$ para $31,7 \%$; apresentou ainda uma redução na renda per capita anual de 82,700 pesos chilenos para 79,000. Situação semelhante pode ser verificada na comuna de Santa Barbara, em que a taxa de pobreza aumentou de 38\% para $43 \%$ no período.

Esse panorama socioeconômico pode ser reflexo do intenso avanço do cultivo florestal registrado desde as décadas de 1970/80. O modelo produtivo vigente na região está estruturado na concentração da propriedade silvícola, processos de cultivos intensivos em capital e tecnologia, além do poder de mercado exercido por grandes corporaçóes industriais e silvícolas que definem o preço dos insumos florestais. Associado a esse cenário tem-se as restriçôes ambientais quanto à diversificação do uso e ocupação da terra agrícola, resultado de séculos de exploração predatória dos recursos naturais na regiáo. 


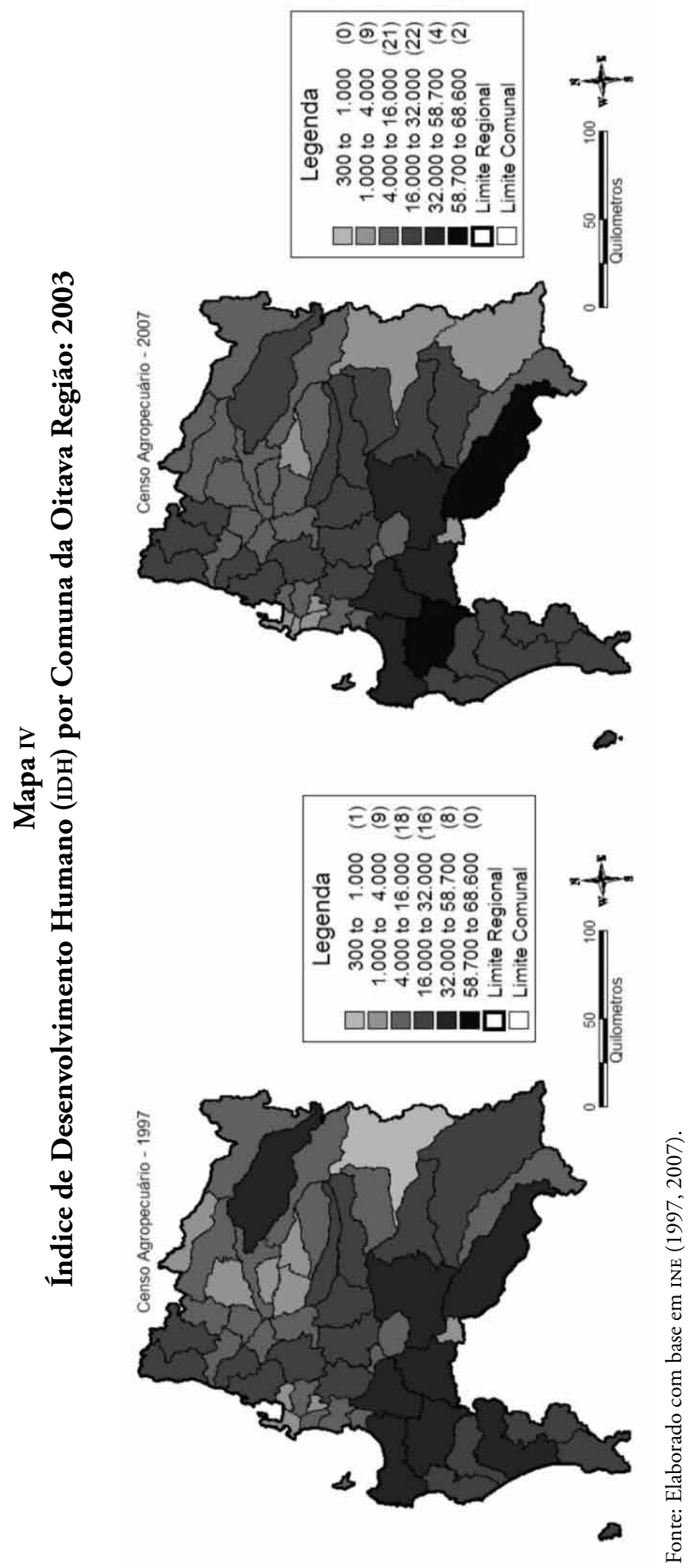


Tabela I

Indicadores sociais para comunas selecionadas da Oitava Regiáo

\begin{tabular}{|c|c|c|c|c|c|c|c|}
\hline \multirow[t]{2}{*}{ Provincia } & \multirow[t]{2}{*}{ Comuna } & \multicolumn{2}{|c|}{$\begin{array}{c}\text { Taxa de Alfabetismo } \\
\text { (\%) }\end{array}$} & \multicolumn{2}{|c|}{ PIB per capita (\$) } & \multicolumn{2}{|c|}{$\begin{array}{c}\text { Taxa de Pobreza } \\
\text { (\%) }\end{array}$} \\
\hline & & 1994 & 2003 & 1994 & 2003 & 1994 & 2003 \\
\hline \multirow{3}{*}{ Bío-Bío } & Nacimiento 4 & 82,0 & 87,2 & 69.537 & 74.260 & 44,1 & 27,7 \\
\hline & Antuco & 86,0 & 89,6 & 52.499 & 55.134 & 37,6 & 31,7 \\
\hline & Cabrero & 81,2 & 87,6 & 45.741 & 56.990 & 45,7 & 41,3 \\
\hline \multirow{6}{*}{ Concepción } & Chiguayante & & 96,8 & & 139.664 & & 22,9 \\
\hline & Concepción & 95,7 & 97,0 & 147.120 & 174.246 & 25,6 & 18,0 \\
\hline & Coronel $^{2}$ & 93,6 & 95,1 & 61.557 & 74.516 & 45,7 & 34,6 \\
\hline & Florida & 75,9 & 81,5 & 51.378 & 63.557 & 43,4 & 36,9 \\
\hline & Hualpén & - & - & - & - & - & 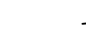 \\
\hline & Hualqui & 83,2 & 89,1 & 47.360 & 64.764 & 57,2 & 29,1 \\
\hline \multirow{4}{*}{ Bío-Bío } & Laja ${ }^{3}$ & 84,8 & 87,1 & 82.670 & 79.337 & 26,6 & 31,7 \\
\hline & Los Ángeles & 88,8 & 91,9 & 75.129 & 95.030 & 39,9 & 25,9 \\
\hline & Mulchén & 83,3 & 86,7 & 39.985 & 65.780 & 62,3 & 39,0 \\
\hline & Negrete & 80,2 & 83,8 & 55.642 & 56.849 & 47,7 & 41,2 \\
\hline Nuble & Pinto & 84,2 & 87,3 & 52.736 & 68.868 & 42,1 & 40,1 \\
\hline \multirow{2}{*}{ Bío-Bío } & Quilaco & 82,8 & 85,8 & 48.163 & 42.008 & 42,8 & 48,8 \\
\hline & Quilleco & 81,0 & 86,0 & 39.350 & 57.118 & 46,1 & 39,8 \\
\hline Nuble & Quillón & 79,9 & 84,7 & 34.809 & 57.147 & 61,5 & 34,4 \\
\hline Concepción & $\begin{array}{l}\text { San Pedro de la } \\
\text { Paz }^{1}\end{array}$ & & 95,7 & & 201.882 & & 24,6 \\
\hline \multirow{2}{*}{ Bío-Bío } & San Rosendo & 87,1 & 90,1 & 62.210 & 62.379 & 55,5 & 31,6 \\
\hline & Santa Bárbara & 73,6 & 82,1 & 59.627 & 76.218 & 37,9 & 43,2 \\
\hline \multirow{2}{*}{ Concepción } & Santa Juana & 76,6 & 83,2 & 55.341 & 59.250 & 45,3 & 31,1 \\
\hline & Talcahuano & 96,3 & 96,7 & 93.002 & 110.043 & 30,1 & 21,3 \\
\hline \multirow{2}{*}{ Bío-Bío } & Tucapel & 84,3 & 89,7 & 40.177 & 63.954 & 60,5 & 35,8 \\
\hline & Yumbel & 78,8 & 84,7 & 54.625 & 65.913 & 47,2 & 30,0 \\
\hline Ñuble & Yungay & 86,0 & 90,3 & 61.332 & 75.970 & 40,3 & 24,0 \\
\hline
\end{tabular}

Nota: 1) Planta Norske Skog. 2) Planta Forestal y Papelera Concepción. 3) Planta Laja - CMPC. 4) Planta Santa Fe I y II - CMPC y Inforsa s.A.

Fonte: Elaborado pelo autor com base em PNUD, 2006.

\section{A atividade silvícola}

\subsection{Silvicultura Chilena}

No Chile as plantaçóes florestais com espécies exóticas ${ }^{2}$ começaram a ser estabelecidas nas primeiras décadas do século Xx. Todavia, somente com globo.

${ }^{2}$ No sentido de que não são nativas do territorio chileno - importadas de outras regiōes do 
a instituição do Decreto Lei no 701/1974 é que se verificou uma grande expansão da superfície florestal, a qual se manteve ao longo dos anos. Estima-se que durante seus primeiros 20 anos de vigência essa lei subsidiou a plantação de aproximadamente 800,000 hectares no país, grande parte na Oitava Região (Infor, 2005: 25).

A partir dos anos 1970 o governo chileno adotou uma política voltada exclusivamente para estimular o setor florestal (cultivo e processamento ou industrial), conhecida como: Politica de Fomento Florestal. Esta política tinha por objetivo estimular a expansão do setor industrial voltado à produção de celulose e papel, mas também incorporava em seu escopo de atuação a atividade silvícola (Chile, 1974).

A implantação da Política de Fomento Florestal foi comandada pela Corporación de Fomento de la Producción (Corfo). No âmbito desta ação foram instaladas algumas das principais unidades produtivas de celulose e papel tais como: Arauco y Constitución em 1972 e 1975, respectivamente (Infor, 2007).

Essa política tinha por base legal o Decreto Lei no 701 de 1974, que dispóe sobre a qualificação dos terrenos aptos ao cultivo florestal, e também sobre os bosques naturais e artificiais que estão sujeitos aos planos de manejo, os quais devem ser aprovados pela Corporación Nacional Forestal (Conaf). O Decreto Lei é considerado o principal instrumento para o grande avanço apresentado pelas atividades silvícolas no país (Chile, 1974). Esse Decreto Lei teve por objetivo regulamentar a atividade florestal, para que ela fosse desenvolvida somente em solos aptos ao cultivo florestal e em solos já degradados (em especial na regiáo central do país, portanto, favorecendo a Oitava Região, em que seus solos foram degradados por décadas pela atividade agrícola extensiva, especialmente pelo cultivo de trigo).

Essa política visava promover uma recuperação ou mesmo a proteção dessas áreas degradadas através do reflorestamento comercial (cultivo de espécies exóticas de alto rendimento) - desenvolvido pelo setor privado. Essa política buscava ainda estimular que a maior parte das plantaçóes fosse desenvolvida no âmbito da pequena propriedade florestal (Chile, 1974). Ou seja, busca-se evitar a presença de grandes áreas homogêneas em termos de vegetação (conhecido como Desertos Verdes), ou mesmo o monocultivo florestal. No entanto, esse objetivo não foi alcançado, em que a Oitava Regiáo acaba por concentrar a maior área de reflorestamento com espécies comerciais de alto rendimento do Chile, sobretudo, a maior parcela se caracteriza por grandes propriedades silvícolas.

Depois de mais de 20 anos de fomento das atividades florestais mediante o Decreto Lei no 701/1974, o congresso chileno fez algumas modificações em 1998. A nova regulamentação manteve a política nacio- 
nal de fomento florestal. O novo aparato de fomento direciona a política para outros agentes, na qual se inclui o estímulo ao cultivo florestal por pequenos produtores (Lei ${ }^{\circ} 19.561$, de 9 abril de 1998, que modifica o D.L. 701 de 1974) (Luraschi, 2007).

Nas últimas décadas o setor florestal chileno tem apresentado importantes transformaçóes, caracterizado por elevadas taxas de crescimento da superfície plantada, volume de produção e de consumo, avanço tecnológico (biotecnologia ou melhoramento genético e pesquisas das espécies de cultivo intensivo), adoção de novas práticas de manejo floresta, entre outras. Esse conjunto características permitiu que o Chile alcançasse um notável grau de competitividade no cenário internacional, tanto na atividade industrial quanto silvícola. Esse quadro também foi possível graças às condiçôes climáticas favoráveis ao cultivo florestal das espécies de pinos e eucaliptos, as principais espécies exóticas cultivadas na Oitava Região.

Em termos de alguns indicadores socioeconômicos relativos ao setor florestal, verifica-se que nos primeiros anos do século xxi esse setor contribuiu em média com 3,8\% do PIB nacional, gerando em torno de 120-130,000 postos de trabalhos diretos e por volta de 300,000 empregos indiretos (Infor, 2006a). Cabe ressaltar ainda sua importância como fonte de divisas internacionais. Este setor exportou em 2007, cerca de US\$ 4'970'000,000,000, representando aproximadamente $7,3 \%$ do montante total das exportaçóes chilenas. Sendo que, por volta de US\$ 2'000'000,000,000 na forma de produtos madeireiros e US\$2'930'000,000,000 correspondendo à indústria de celulose e papel (Banco Central, 2008).

O setor florestal tornou-se uma das atividades mais dinâmicas e importantes da economia chilena, constituindo-se em um pilar fundamental da estratégia de desenvolvimento nacional com amplo reconhecimento internacional. A atividade silvícola encontra-se vinculada direta e indiretamente ao setor externo, na medida em que parte significativa da produçáo florestal é transformada em celulose e/ou papel, destinada à exportação. Em paralelo, esse setor tem evoluído no mesmo caminho das exigências dos mercados internacionais, refletindo-se em um ambiente de permanente modernização tecnológica, tanto em termos dos processos produtivos quanto na minimização dos impactos ambientais.

Praticamente todo o recurso florestal que sustenta o setor industrial chileno provém de florestas plantadas (reflorestamento), em que as espécies mais importantes são o Pino radiata e Eucaliptus globulus e Eucaliptus nitens. A superfície média anual de plantação florestal no território chileno dos últimos 20 anos tem superado aos 95,000 hectares, sendo que, entre 2000-2004 tem sido registrada uma média de 117,000 hectares (Infor, 2005). 
Segundo dados do Censo Agropecuário Chileno de 1997, o uso do recurso florestal representado pelas plantaçóes artificiais ocupava em 1997 uma área de aproximadamente de 2’190,000 hectares, distribuída da seguinte maneira: $76 \%$ com pinos, $21 \%$ com eucaliptos e o restante com outras espécies (INE, 1997) (tabela II).

\section{Tabela II}

Estimativa da área coberta com florestas plantadas e nativas segundo cada regiáo chilena e principais espécies plantadas: 1997

\begin{tabular}{lrrrr}
\hline \multirow{2}{*}{ Regiäo } & \multicolumn{4}{c}{ Censo Agropecuário -1997 (em hectares) } \\
\cline { 2 - 5 } & Eucaliptos & Pinos & $\begin{array}{c}\text { Outras } \\
\text { Espécies }\end{array}$ & Total \\
\hline Chile & 462.317 & 1.655 .017 & 75.729 & 2.193 .062 \\
I de Tarapacá & 0 & 0 & 0 & 0 \\
II de Antofagasta & 0 & 0 & 875 & 876 \\
III de Atacama & 609 & 32 & 32 & 673 \\
IV de Coquimbo & 3.820 & 9 & 571 & 4.400 \\
V de Valparaíso & 41.515 & 16.596 & 2.733 & 60.844 \\
VI de O’Higgins & 31.344 & 73.786 & 7.024 & 112.153 \\
VII del Maule & 32.216 & 378.833 & 15.301 & 426.351 \\
VIII del Bío Bío & 157.292 & 716.235 & 14.363 & 887.890 \\
IX de La Araucanía & 122.713 & 327.156 & 15.956 & 465.824 \\
X de Los Lagos & 65.064 & 141.920 & 11.568 & 218.551 \\
XI Aysen & 0 & 0 & 0 & 0 \\
XII de Magallanes y Antártica & 4 & 13 & 49 & 66 \\
Región Metropolitana de Santiago & 7.745 & 450 & 7.305 & 15.501 \\
XIV de Los Ríos & 0 & 0 & 0 & 0 \\
Xv de Arica y Parinacota & 0 & 0 & 0 & 0 \\
\hline
\end{tabular}

Fonte: Elaborado com base em INE (1997).

Em uma década a atividade silvícola baseada no cultivo de pinos e eucaliptos apresentou um importante e intenso avanço. Segundo dados do Censo Agropecuário Chileno de 2007, a superfície cultivada total alcançou 2'670,000 de hectares, um aumento de 477,700 hectares em uma década, ou seja, um avanço na área cultivada $21,8 \%$ maior do que os dados apresentados no último censo agropecuário. Destaca-se que somente as espécies de eucaliptos (globulus e nitens) apresentaram um aumento da ordem de 93,4\%, um incremento de pouco mais de 431,000 hectares, alcançando em 2007, 894,300 hectares. Por um lado, a área cultivada com pinos (radiata e oregon), pelo menos em termos absolutos, praticamente foi mantida, em torno de 1'650,000 de hectares. Por outro, em termos relativos à superfície cultivada com pinos recuou para $62 \%$, 


\section{Tabela III}

\section{Estimativa da área coberta com florestas plantadas e nativas segundo cada regiáo chilena e principais espécies plantadas: 2007}

\begin{tabular}{lrrrr}
\hline \multirow{2}{*}{ Região } & \multicolumn{4}{c}{ Censo Agropecuário - 2007 (em hectares) } \\
\cline { 2 - 5 } & Eucaliptos & Pinos & $\begin{array}{c}\text { Outras } \\
\text { espécies }\end{array}$ \\
\hline Chile & 894.288 & 1.653 .896 & 122.573 & 2.670 .757 \\
I de Tarapacá & 0 & 0 & 50.429 & 50.429 \\
II de Antofagasta & 0 & 0 & 591 & 591 \\
III de Atacama & 297 & 0 & 9 & 305 \\
IV de Coquimbo & 3.262 & 1 & 1.892 & 5.155 \\
V de Valparaíso & 42.419 & 11.682 & 2.170 & 56.271 \\
VI de O’Higgins & 48.653 & 83.264 & 3.469 & 135.387 \\
VII del Maule & 51.184 & 434.642 & 5.405 & 491.231 \\
VIII del Bío Bío & 309.577 & 653.167 & 10.519 & 973.263 \\
IX de La Araucanía & 248.061 & 329.405 & 9.371 & 586.837 \\
X de Los Lagos & 61.322 & 23.643 & 3.412 & 88.376 \\
XI Aysen & 11 & 8.065 & 19.955 & 28.031 \\
XII de Magallanes y Antártica & 0 & 0 & 2 & 2 \\
Región Metropolitana de Santiago & 7.429 & 31 & 1.273 & 8.734 \\
XIV de Los Ríos & 122.069 & 109.996 & 14.070 & 246.135 \\
XV de Arica y Parinacota & 5 & 0 & 6 & 11 \\
\hline
\end{tabular}

Fonte: Elaborado com base em INE (2007).

ou seja, sua participação sofreu uma redução de aproximadamente 13,5\% em relação a 1997 (INE, 2007) (ver tabela III).

Observa-se, portanto, que o período recente é marcado por uma importante alteração na composição da estrutura silvícola chilena, influenciada fortemente pelo maior crescimento da área cultivada com as espécies de eucaliptos. Em 2007, o cultivo de eucaliptos representava em torno de $33,5 \%$ da área florestal (um aumento de 12,5\% em relação ao censo de 1997) (INE, 2007).

As principais regiôes chilenas em termos da superfície cultivada com pinos e eucaliptos são: Sétima Região - Del Maule; Oitava Região - Del Bío Bío; Ix Região - De la Araucanía; xiv Região - De los Ríos. Esse conjunto de regiōes respondia em 2007 por volta de 85\% da superfície total cultivada no Chile. Somente a Oitava Regiáo respondia por $36 \%$ da área total (tabela III), evidenciando a concentração espacial da atividade silvícola.

Em termos das perspectivas futuras da atividade silvícola, o Chile dispóe de aproximadamente 33'800,000 de hectares (44,6\% do território nacional) com aptidão para o cultivo florestal. Estimou-se que em 2005, 
os bosques nativos e as plantaçóes florestais ocupavam uma superfície da ordem de $15,600,000$ de hectares (20,7\% do território nacional) (Infor, 2005). Portanto, existe um grande espaço para a expansão dessa atividade.

Diante deste cenário favorável, segundo Infor (2005: 30), o Chile experimentará nos próximos anos um expressivo aumento da produçáo de madeira advinda dos cultivos comerciais de espécies de alto rendimento. De acordo com estimativas realizadas por esta instituição, a produção passaria dos atuais $36^{\prime} 000,000 \mathrm{de} \mathrm{m}^{3}$ anuais para $45^{\prime} 000,000 \mathrm{~m}^{3} \mathrm{em} 2020$, ou seja, um crescimento de $30 \%$. Em termos das espécies, estimase que a

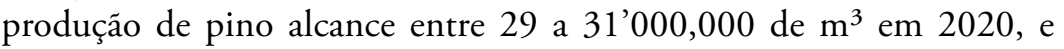
$39 ’ 000,000 \mathrm{de} \mathrm{m}^{3} \mathrm{em} 2030$. O eucalipto apresentaria uma expansão ainda mais intensa, passando dos atuais $5^{\prime} 000,000 \mathrm{de}^{3}$ para $14{ }^{\prime} 000,000$ $\mathrm{de}^{3} \mathrm{em} 2020$, praticamente triplicando o volume produzido (Infor, 2005).

Cabe destacar que o consumo de madeira já superou o volume estimado de produçáo de madeira advindas das áreas de reflorestamento de pino e eucalipto para 2020. Isto pode significar que grande parte da madeira consumida no Chile ainda provém das florestas nativas. Em 2005, o consumo nacional alcançou 46000,000 $\mathrm{de}^{3}$, muito acima do que havia sido estimado para 2020 (Infor, 2006b).

Segundo Luraschi, Marcos (2007), a expansão das plantaçóes florestais realizar-se-á especialmente em solos da zona denominada Zona de Secano no Centro-Sul do país, onde se localiza a Oitava Região. Essa zona tem uma distribuição estacional de chuvas que dificulta o desenvolvimento da atividade agropecuária que não se baseia no sistema irrigado. Além disso, a topografia (elevada declividade) da região dificulta a implantação de sistemas de irrigação. Ainda, grande parte dessa regiáo se caracteriza pela presença de superfícies com solos degradados decorrentes do cultivo agrícola em meados do século xx.

Em resumo, a história da silvicultura chilena é caracterizada basicamente pela intervenção estatal na dinâmica dessa atividade, buscando estimular à expansão do setor silvícola paralela a atividade industrial. Neste contexto, a Oitava Região ocupa um papel central seja na produção florestal propriamente dita seja na atividade industrial.

\subsection{Análise Espacial-Comparativa da Dinâmica da Atividade Silvícola na Oitava Regiáo: 1997/2007}

O setor florestal chileno e, particularmente o sistema instalado na Oitava Região baseiam-se no cultivo das espécies de alto crescimento, tais como: pinus radiata D. Don (Pino insigne, Pino radiata, Pino monterrey y Pino) e de Eucalyptus globulus Labill (Eucalipto, Gomero Azul, Calipto, Caliuto) e Eucalyptus nitens Maiden, (Eucalipto) (Conaf, 2008b). Embora, as 
principais espécies cultivadas na Oitava Regiáo sejam o Pino insigne e radiata e o Eucalyptus globulus e nitens.

O Pino radiata é originário da costa ocidental dos Estados Unidos, especificamente do Estado da Califórnia. Essa espécie foi introduzida no Chile em fins do século XIX, sem fins comerciais, embora tenha apresentado uma rápida adaptação ao clima e solo, inclusive alcançando em algumas regióes crescimento superior, e, em menor tempo, se comparado indicadores de sua regiáo de origem (Luraschi, 2007; Conaf, 2008b). No início, a madeira produzida pelas primeiras plantaçóes foi utilizada na estrutura das minas subterrâneas de carvão localizadas próximas as Comunas de Coronel e Lota, ambas localizadas na Oitava Regiáo, porém sem êxito. Posteriormente, o pino substituído pelo eucalipto que se mostrou mais resistente às condiçóes impostas pelas minas de carvão.

Segundo dados do Censo Agropecuário Chileno de 2007, a Oitava Região concentra em torno de 36\% (973,300 hectares) da superfície total cultivada no Chile (2'670,000 de hectares), seguida pela Nona Região com $22 \%$ e, pela Sétima Região com $18 \%$ (INE, 2007). É evidente a relevância da Oitava Regiáo na estrutura produtiva florestal chilena e as perspectivas de expansão do cultivo florestal para os próximos anos, segundo estimativas realizadas pelo Infor (2005), sustentam a importância de se realizar uma análise sobre a estrutura desse setor na regiáo, sem contar a questão controversa dos impactos ambientais associados ao cultivo florestal.

As informações apresentadas no mapa $\mathrm{v}$ mostram que ocorreu um aumento significativo na área média silvícola por comuna. Em 1997, a menor superfície territorial dedicada à silvicultura era de 386 hectares (Comuna de Antuco), por sua vez, em 2007, o menor território saltou para 1.044 hectares (Comuna Alto Bío Bío), representando um aumento de $170 \%$. Em relação a Comuna de Antuco, a área cultivada saltou para 1.181 hectares, registrando um incremento da ordem de 206\%. A Oitava Região tem 54 comunas, destas apenas 24 tinham uma superfície cultivada com pinos e/ou eucaliptos inferior a 10,000 hectares (INE, 1997, 2007).

Observa-se uma dinâmica semelhante em relação à maior superfície comunal com cultivo silvícola, em 1997 foi registrada uma área de 58,600 hectares (Comuna de Curanilahue), em 2007 a maior área silvícola passou para 68,600 hectares (Comuna de Mulchen). A Comuna de Curanilabue registrou um avanço na área cultivada de 2,4\% (59,900 hectares). Em 1997, as cinco comunas que tinham as maiores áreas de cultivo respondiam por 26\% (235,000 hectares) da área total cultivada na regiáo. Quando se considera apenas as comunas com áreas cultivadas superiores a 30,000 hectares, um total de nove, esse percentual sobe para 42\% (371,500 hectares). Em 2007, as cinco comunas com as maiores áreas continuam 


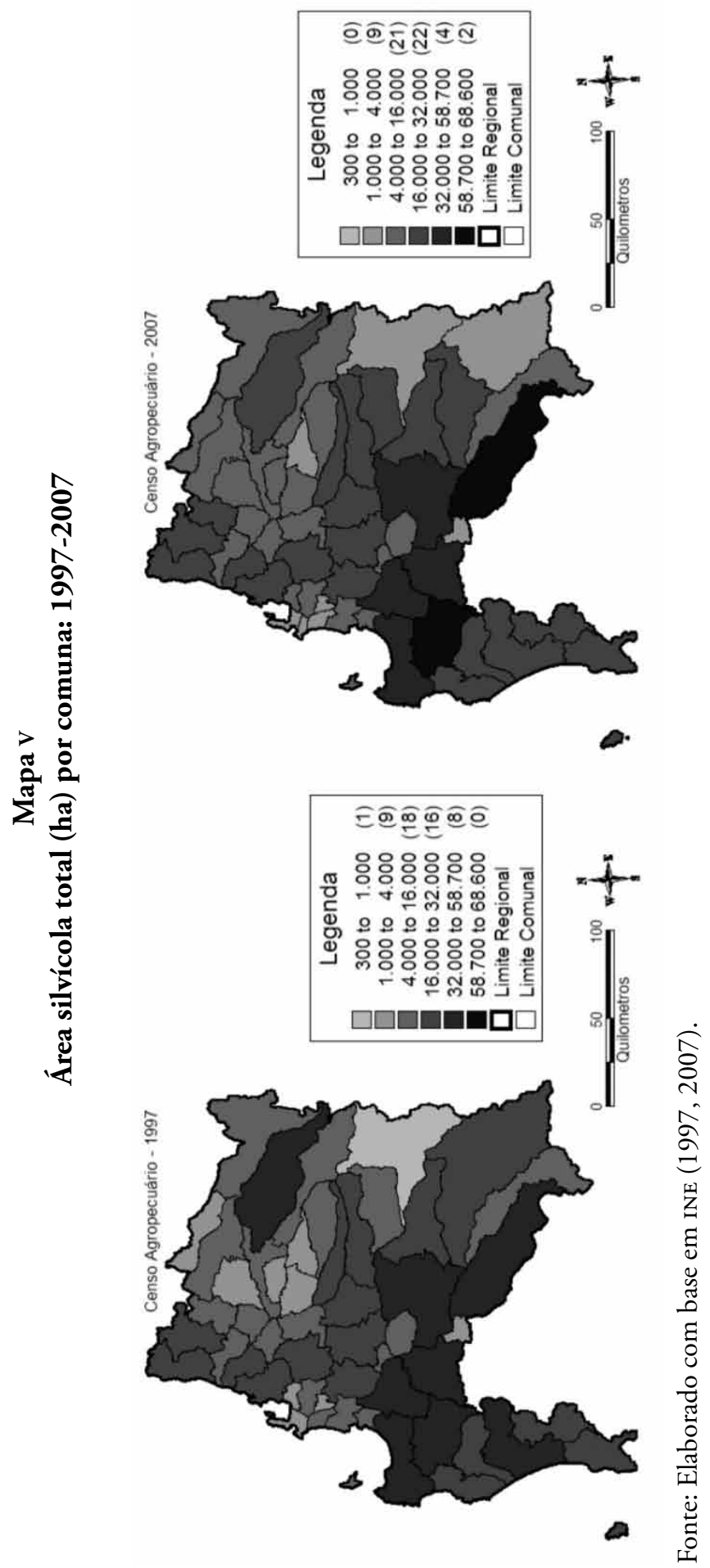


respondendo por $26 \%$ da área total cultivada, mas a área desse grupo subiu para 256,700 hectares, um acréscimo de $9 \%$. Por sua vez, as comunas com áreas cultivadas superiores a 30,000 hectares eram 11, que passaram a responder por $46 \%$, e a área do grupo passou para 450,000 hectares, um acréscimo de $21 \%$ (INE, 1997, 2007).

O aumento da área cultivada ocorreu basicamente nas comunas localizadas no norte e noroeste da Oitava Região. Nestas áreas se localizam as principais empresas industriais do setor de celulose e papel, portanto, demandam grande quantidade de matéria-prima silvícola para seus processos $^{3}$. Porém, outro elemento relevante que pode ser destacado são as características dos solos (com elevada aptidáo silvícola) e a disponibilidade hídrica, pois os terrenos estáo localizados próximos a um importante rio chileno, o rio Bío Bío.

É possível ainda fazer uma análise relacional entre a área silvícola cultivada apenas com pinos e eucaliptos e o território da comuna, ou seja, verificar a participação percentual da superfície silvícola comercial em relação à superfície total de cada comuna. Esse percentual pode indicar se existe uma tendência ao monocultivo florestal ou não, que indique um movimento para a homogeneização de determinados territórios.

Essa informação é apresentada no mapa vi, em que é possível verificar que em 1997 as maiores participaçóes relativas alcançavam entre $45 \%$ e 63\% (verificado em sete comunas), ou seja, mais da metade do território da comuna estava ocupada por florestas de pinos e eucaliptos. Por sua vez, em 2007, a maior participação relativa alcançou $75 \%$, praticamente toda a área da comuna de Lota (única área com a cor preta no mapa vi) estava ocupada por plantaçóes florestais, ou seja, caracterizando um monocultivo. Cabe destacar ainda que no intervalo de $45 \%$ a $63 \%$ da área da comuna ocupada com cultivo silvícola é verificado em 14 comunas, dobrando o número de comunas neste intervalo. Ainda, a maior parte dessas comunas está localizada na faixa litorânea sentido noroeste da Oitava Região, a grande mancha cinza escuro no mapa vi, com exceção de uma comuna que se localiza na regiáo central.

É oportuno analisar também a distribuição da superfície silvícola em termos das principais espécies cultivadas na Oitava Região: Pino radiata e óregon (Pinos) e Eucaliptos globulus e nitens (Eucaliptos). Com base no mapa vil verifica-se que a menor superfície com eucaliptos aumentou de 3\% (858 hectares) em 1997 para 7,9\% (2.446 hectares) (Comuna de Cabrero) em 2007, portanto, um crescimento da ordem de 160\%. Além

\footnotetext{
${ }^{3}$ As unidades produtivas de celulose instaladas na viır Regiáo têm uma capacidade instalada anual da ordem de 1'800,000 toneladas, e as papeleiras da ordem de 410,000 toneladas (CMPCCelulosa, 2008; Inforsa, 2008; Norske Skog Bio Bio, 2008).
} 


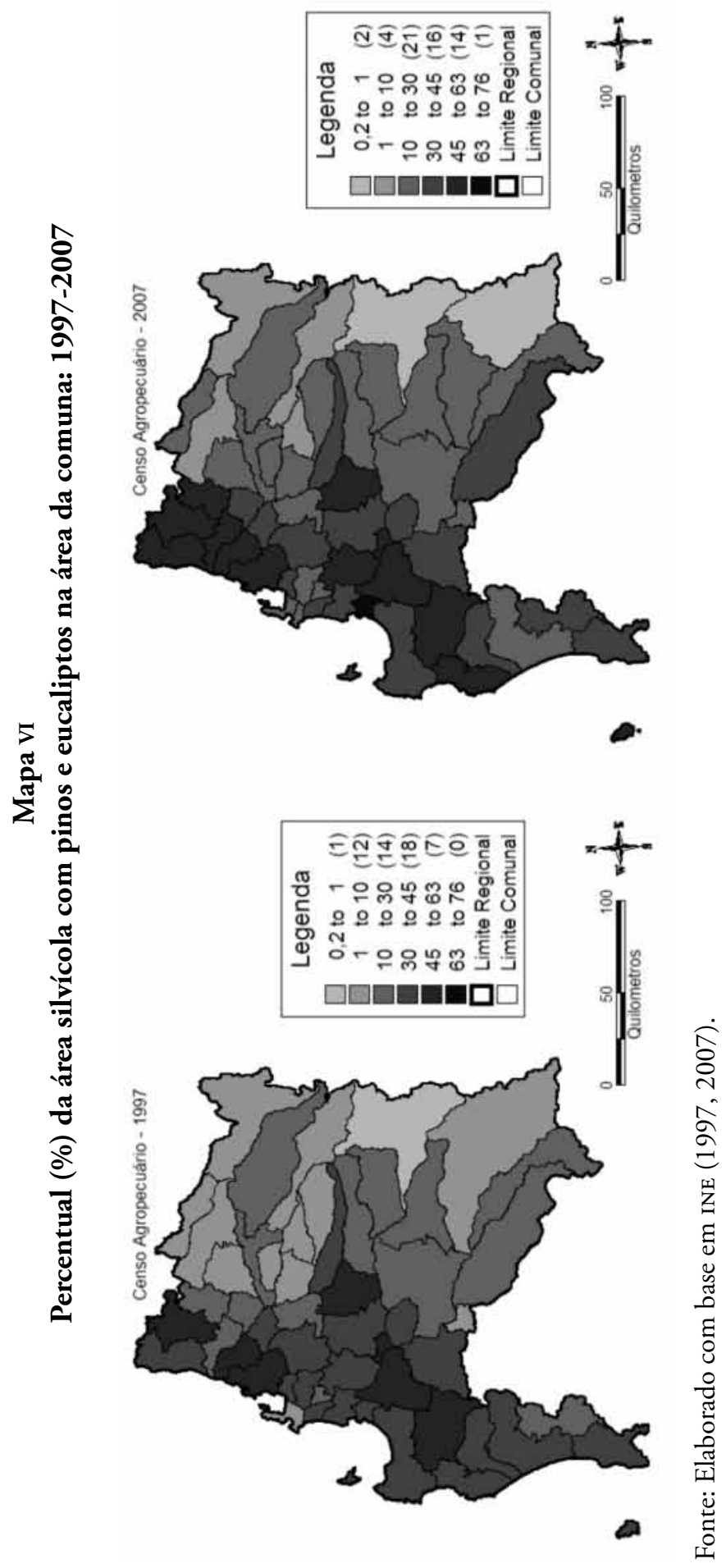




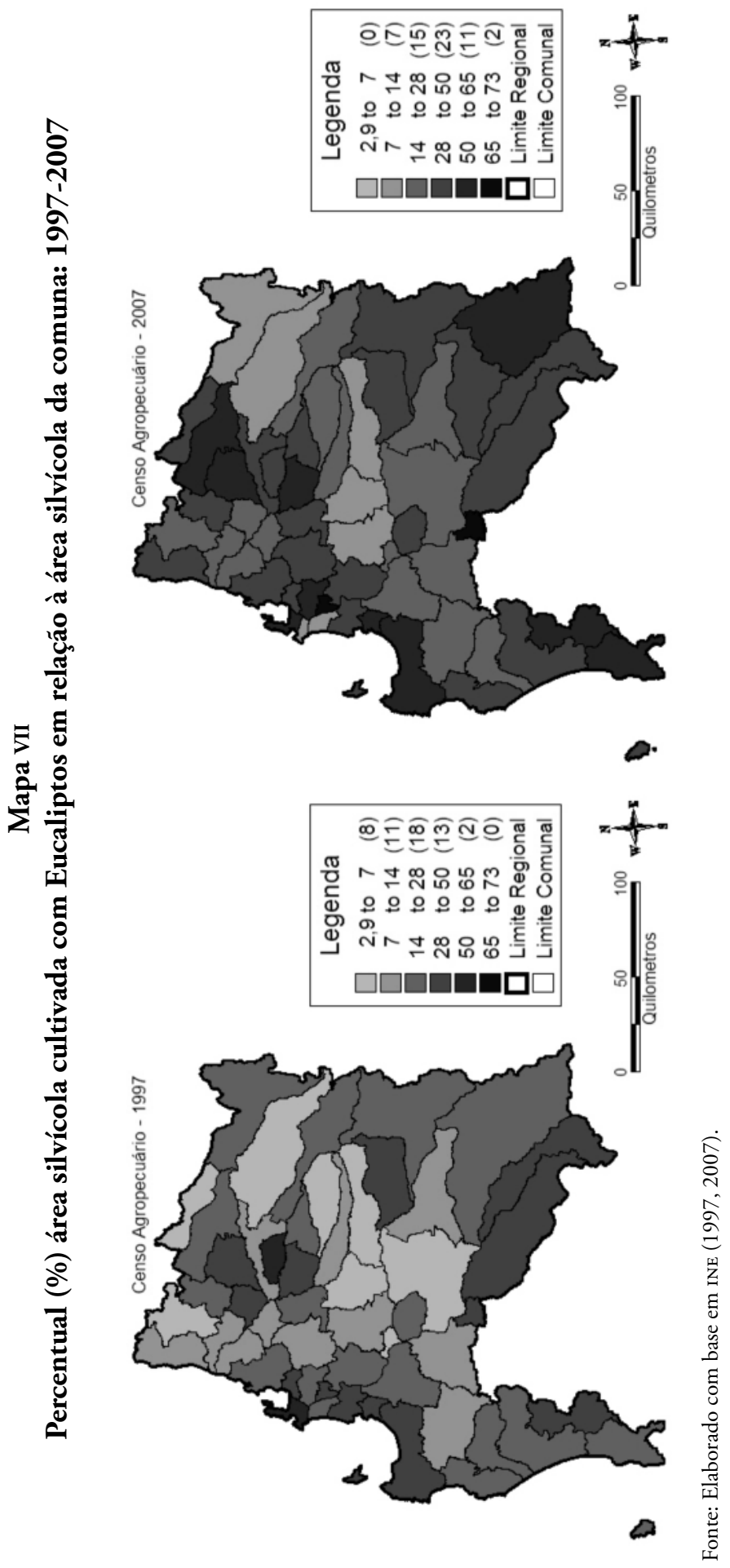


disso, apenas quatro comunas tinham uma participação relativa do cultivo de eucaliptos inferior a $10 \% \mathrm{da}$ área cultivada total (INE, 1997, 2007).

Constata-se também que a maior participação relativa aumentou de 64,9\% (1.035 hectares) (Comuna de Chillán Viejo) registrada em 1997 para 72,4\% (1.053 hectares) (Comuna de Chiguayante) em 2007. Do total de comunas da Oitava Região, em 22 delas a área cultivada com eucalipto era superior a $40 \%$ (INE, 1997, 2007). Essa expansão no cultivo de eucaliptos no período pode ter sido fortemente influenciada pelo projeto de ampliação e em entrada em operação da Planta Santa Fé da CMPC-Celulosa. Essa planta industrial é a maior unidade produtiva do mundo de celulose química (ou Kraft) de fibra curta, ou seja, a base de madeira de eucalipto. Essa unidade produtiva tem uma capacidade instalada da ordem de 1'160,000 de toneladas de celulose química por ano (CMPC - Companía Manufacturera de Papeles y Cartones, 2007).

Logo, observa-se uma redução na participação relativa do cultivo das espécies de pinos na superfície silvícola total das comunas no período. É possível verificar essa afirmação no mapa vıII, em que a menor participação relativa em 1997 era de 20,9\% sobre a superfície silvícola total (Comuna de Chillán Viejo), porém em 2007, essa participação foi reduzida para 5,2\% (Comuna de Hualpen), representando uma redução da ordem de $300 \%$ em uma década. Embora tenha sido registrado em Chillán Veijo um avanço do cultivo de pinos para $56 \%$, enquanto a parcela com eucalipto corresponde a 42\% (INE, 1997, 2007).

A tendência de substituição do cultivo de pinos por eucaliptos verifica-se nas comunas em que havia um predomínio das espécies de pinos sobre as espécies de eucaliptos, que alcançava em 1997, uma participação relativa da ordem de $95,9 \%$ da superfície silvícola total (Comuna de $E l$ Carmen) para 91,5\% em 2007 (Comuna de San Fabián). Portanto, no período analisado é possível inferir que pode estar ocorrendo à substituição das áreas cultivadas com as espécies de pinos por espécies de eucaliptos na Oitava Região.

Ademais, uma última análise que é possível fazer diz respeito ao crescimento percentual da superfície silvícola na comuna para o período 1997/2007. No mapa Ix é possível observar que algumas comunas apresentaram forte redução na área silvícola, algumas registraram queda de até 50\% se comparada à superfície silvícola registrada em 1997 (Comuna de San Fabián), em relação à área silvícola registrada em 2007 pelo Censo Agropecuário.

Por outro lado, algumas comunas entraram na pauta da expansão da atividade silvícola chilena, pois em praticamente uma década a superfície plantada aumentou em até 328\% (Comuna de San Nicolás), sendo que diversas comunas dobraram o tamanho da área dedicada à silvicultura 


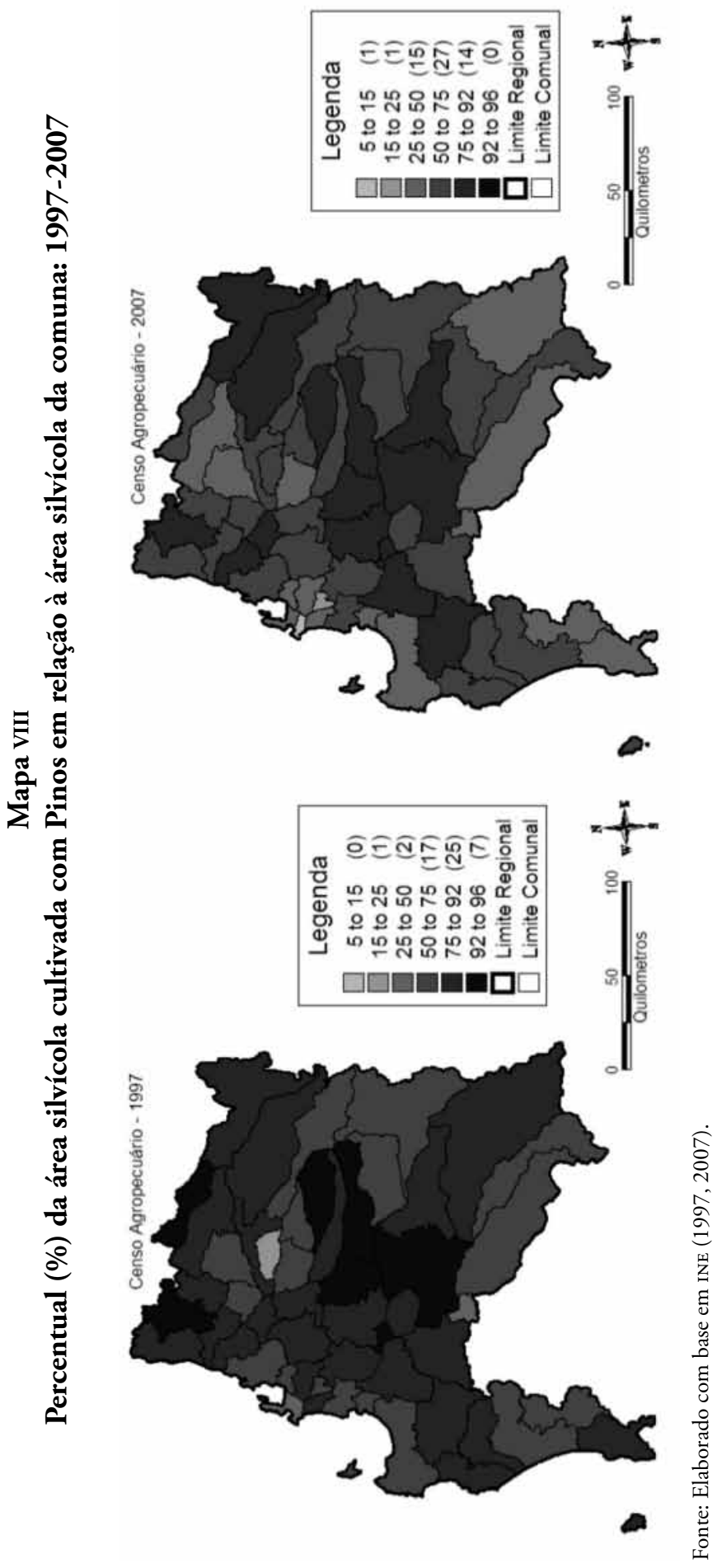


como se pode observar no mapa Ix. Cabe ressaltar que importantes comunas, em termos de estrutura hídrica estão entre aquelas que expandiram sua área silvícola. Ainda é possível observar comunas que apresentaram crescimento superior a 100\% (San Nicolás, Chillán Viejo, Antuco e Ninhue) em sua superfície utilizada para a atividade silvícola concentram importantes estruturas hídricas.

Outro aspecto relevante é que as comunas localizadas no CentroNordeste da Oitava Região são áreas dedicadas à atividade agrícola. Portanto, é possível inferir que a silvicultura esteja se expandindo em áreas que antes estavam sendo dedicadas à produção agrícola. Por exemplo, a área dedica ao cultivo agrícola (culturas temporárias e permanentes) registrada sofreu uma redução de 62,000 hectares, de 272,700 hectares em 1997, para 210,000 hectares em 2007, ou seja, uma queda de 23\% (INE, 1997, 2007). No mapa x é apresentada a taxa de evolução da área agrícola cultivada com culturas temporárias e permanentes entre 1997 e 2007.

No mapa x é possível verificar uma redução na área cultivada com culturas temporárias e permanentes, que alcançou até $100 \%$ na área agrícola. Por exemplo, a comuna de Quilleco em 1997 tinha uma área agrícola da ordem de 9,000 hectares, em 2007, ocupava apenas 3,100 hectares, redução de $65 \%$.

Um último aspecto a ser considerado é a questão da mata ciliar, porém não seja possível com base nos dados censitários fazer uma inferência mais acurada. Mas, a partir das informaçóes sobre a superfície com cobertura vegetal/florestal nativa ou natural registrada na Oitava Região é possível verificar que ocorreu uma redução de $25 \%$, em torno de 240,000 hectares foram desmatados (INE, 1997, 2007). Contudo, não é possível afirmar se as áreas com florestas nativas desmatadas foram convertidas em plantaçóes florestais comerciais. Diante desse contexto, será que os produtores silvícolas estarão respeitando as áreas que devem ser preservadas, formando assim a mata ciliar?

Nesta análise foi possível verificar que o setor silvícola instalado na Oitava Região sofreu profundas transformações estruturais entre os dois censos agropecuários realizados em 1997 e 2007. Dentre elas têm-se a forte expansão da superfície silvícola, especialmente em áreas antes dedicadas a atividade agrícola, além de ter ocorrido uma importante alteração na composição das espécies cultivadas. Essa alteração ficou evidente pelo aumento da superfície plantada com as espécies de eucaliptos, que no limite pode ter conduzido a substituiçôes de áreas cultivadas com espécies de pinos. 


\section{Mapa IX}

Crescimento percentual (\%) médio da superfície silvícola na Oitava Regiáo por comunas: 2007/1997

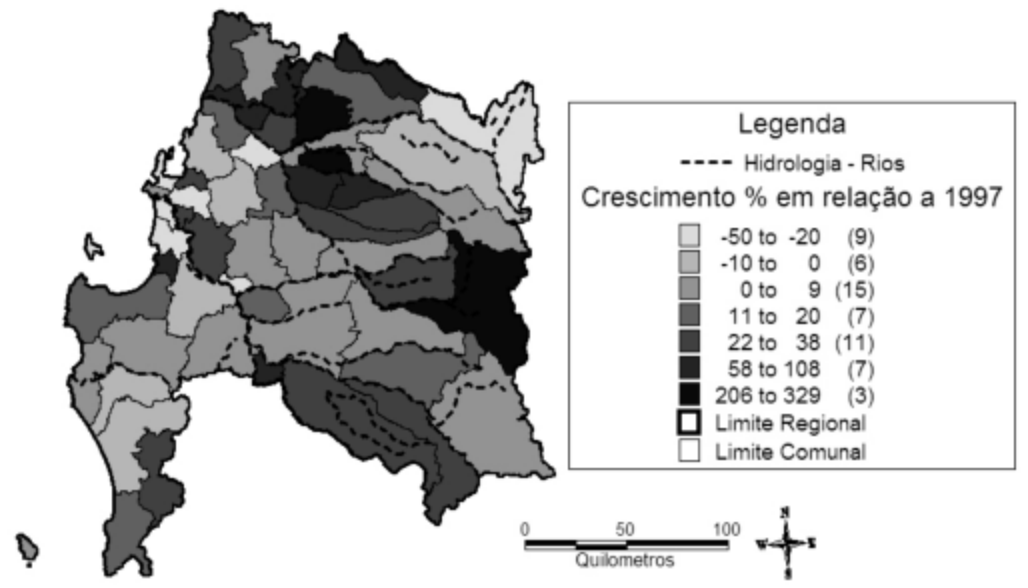

Fonte: elaborado com base em INE $(1997,2007)$.

\section{Mapa X}

Variaçáo percentual (\%) média da superfície agrícola na Oitava

Regiáo por comunas: 2007/1997

\section{Legenda}

$\square$ Limites Regionais Variação \%

$\square-100 \%--50 \%$

$-49 \%--25 \%$

$-22 \%-0 \%$

- $3 \%-10 \%$

- $82 \%-177 \%$
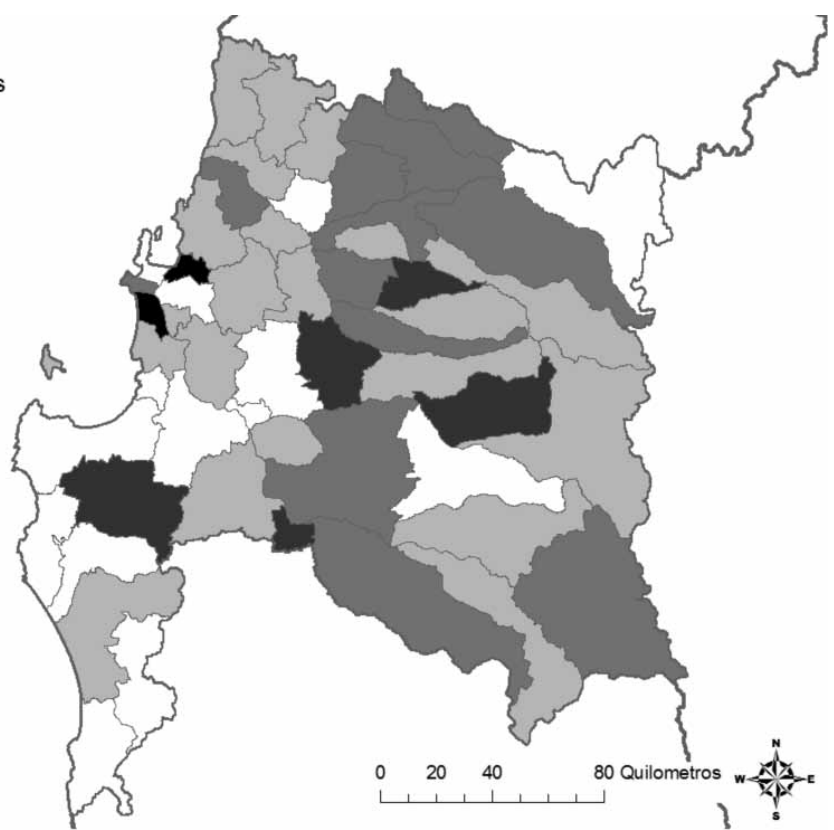

80 Quilometros

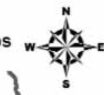

Fonte: Elaborado com base em INE $(1997,2007)$. 


\section{Consideraçóes finais}

Este trabalho procurou analisar as transformações estruturais da atividade silvícola desenvolvida na Oitava Regiāo Chilena a partir da espacialização dos dados levantados pelo Censo Agropecuário Chileno para o período 1997-2007. Com base na análise realizada é possível questionar sobre quais foram as principais implicações dessas transformaçōes sobre o espaço regional em termos socioeconômicos e ambientais, especialmente em termos dos impactos ambientais associados à atividade silvícola?

Em relação aos aspectos socioeconômicos, a primeira importante informação refere-se à elevada concentração da estrutura produtiva silvícola chilena em apenas poucas regióes. Em torno de 77\% (2'050,000 de hectares) da superfície silvícola nacional (2'760,000 de hectares) encontrase localizada em apenas três regióes: Sétima, Oitava e Nona. Somente a Oitava Região responde por $36 \%$ da superfície nacional dedicada a silvicultura, uma área de 973,000 hectares (INE, 1997, 2007). Essa estrutura pode indicar que existe uma tendência ao monocultivo silvícola em determinadas áreas do território nacional.

A Oitava Regiáo representa o segundo polo econômico do país, contribuindo em média com 9\% do Produto Interno Bruto (PIB). Uma importante parcela da atividade industrial instalada na regiáo está diretamente vinculada à silvicultura, representada pela produção de celulose, papel, serrarias e atividades de processamento da madeira. A atividade agro-silvícola responde em média por $6 \%$ do PIB regional, e o setor industrial por $36 \%$.

Mesmo a Oitava Regiáo ocupando o segundo lugar em importância econômica, apresenta uma dos menores Índices de Desenvolvimento Humano (IDH) dentre as regióes chilenas, ocupando em 2003 a décima posição no ranking nacional. $\mathrm{O}$ IDH nacional era de $0,725 \mathrm{em} 2003$, mas o índice verificado na Oitava Regiáo era de 0,686. A maior parte das comunas apresentam índices entre 0,562 e 0,653. As comunas que apresentavam os maiores IDH regionais estão localizadas na área metropolitana de Concepción e algumas distribuídas no centro-sul e leste da Oitava Região (PNUD, 2006).

Um aspecto que merece destaque é o fato de que o conjunto de comunas com IDH entre 0,562 e 0,611 (menor intervalo verificado) concentre por volta de $18,5 \%$ (182,000 hectares) da área silvícola regional, ademais, a área média das comunas destinadas à silvicultura é da ordem de $35 \%$. Um resultado interesse é a comparação do resultado do IDH registrado em 2003 com os índices observados em 1994. Observa-se que o conjunto das comunas apresentou uma significativa melhora. $\mathrm{O}$ IDH 
para o conjunto das comunas registrou um aumento em média de 19\%, saltando de um IDH conjunto de 0,500 para 0,592 (PNUD, 2006).

No que se refere aos aspectos ambientais, segundo Plaza de los Reyes Del Río, Catalina (2008), os principais impactos ambientais associados à atividade silvícola são: contaminação do ar decorrente de diversas fontes de emissóes, por exemplo, utilização de máquinas auxiliares; contaminação por geração de resíduos sólidos, os quais podem ser arrastados para os corpos d'água; alteraçôes na estrutura hidrológica da regiáo; contaminação hídrica (águas superficiais e subterrâneas) associada ao uso de herbicidas e ao arraste de matéria orgânica etc.; alteraçôes nos processos de erosão de solos decorrentes das práticas de manejo florestal (corte das árvores pelo método conhecido como tala rasa, isto é, o solo ficaria descoberto por um longo período de tempo, portanto, sujeito à erosão hídrica e eólica); contaminação por resíduos líquidos tais como combustíveis e óleos diversos; destruição de habitat naturais, dado que há um predomínio de uma única espécie no cultivo florestal entre outros.

Considerando que praticamente um terço do território da Oitava Região esteja ocupado pelo cultivo silvícola, as pressóes sobre os ecossistemas se intensificam, especialmente pela probabilidade de expansão da atividade. Ainda, conforme verificado nos dados censitários, no período analisado é possível observar uma redução da ordem de 240,000 hectares da cobertura vegetal nativa (INE, 1997, 2007), ou seja, intensificação do uso do solo para atividades econômicas, tais como urbano, industrial, agrícola e silvícola.

Em síntese, a análise espacial-comparativa empreendida pode ser utilizada como subsídio para a formulaçáo de políticas públicas, fiscalização ambiental, e para que se possa acompanhar a dinâmica de ocupação e uso do solo, especialmente das atividades intensivas no uso deste recurso natural. Logo, as informaçóes observadas poderiam auxiliar também na elaboração de planos de manejo mais adequados, especialmente nos territórios que abrigam um grande número de corpos d'águas como é o caso da Oitava Região em que há anos sofre stress hídrico.

\section{Referências bibliográficas}

BC (Banco Central) (2008), Diversas informaçôes econômicas, <http://www. bcentral.cl/>, 25 março 2008.

BC (Banco Central) (2010), Cuentas nacionales, <www.bcentral.cl>, 12 março 2011. 
Chile (1974), Decreto no 701, Ley de Fomento Forestal, <www.conaf. cl>, 25 janeiro 2008 .

Chile (1994), Ley de Bases del Medio Ambiente, <www.conaf.cl>, 25 janeiro 2008.

CMPC (Companía Manufacturera de Papeles y Cartones) (2007), Memoria Corporativa 2007. <www.cmpc.cl>, 15 maio 2008.

CMPc-Celulosa (2008), Nuestra Empresa, <http://www.cmpccelulosa.cl/ espanol/about_us/about_us.htm>, 18 fevereiro 2008.

Conaf (Corporación Nacional Forestal-Chile) (2008a), Arquivos shapefile da Oitava Região. escritório do Conaf Bío Bío, 20 abril 2008 em visita ao escritório.

Conaf (Corporación Nacional Forestal-Chile) (2008b), Ley de Recuperación del Bosque Nativo y Fomento Forestal (Título Preliminar), $<$ www.conaf.cl>, 15 maio 2008.

i-CET (Sistema de Consulta Estadístico Territorial) (2009a), Información Censal-Plantaciones Forestales. <http://icet.siigsa.cl/>, 15 abril 2009.

i-CET (Sistema de Consulta Estadístico Territorial) (2009b), Información Censal-Forestal, <http://icet.siigsa.cl/>, 15 abril 2009.

i-CET (Sistema de Consulta Estadístico Territorial) (2009c), Cartografía y Coberturas Shape Descargables, <http://icet.siigsa.cl/>, 15 abril 2009.

INE (Instituto Nacional de Estadística) (1997), "Estadísticas Agropecuarias-VI Censo Agropecuario 1997”, <www.ine.cl/>, 15 abril 2009.

INE (Instituto Nacional de Estadística) (2007), Estadística AgropecuariasCenso Agropecuario 2007, <www.ine.cl/>, 15 abril 2009.

INE (Instituto Nacional de Estadística) (2002). Censos de Población y Vivienda, <www.ine.cl/>, 17 abril 2009.

Infor (Instituto Forestal de Chile) (2005), El sector forestal chileno en una mirada, <http://www.infor.cl/>, 25 fevereiro 2008. 
Infor (Instituto Forestal de Chile) (2006a), Estadísticas de empleo. Disponível em <www.infor.cl> Acesso: 22 abril 2008.

Infor (Instituto Forestal de Chile) (2006b), Superficie de plantaciones forestales IV a XI regiones actualizacion a diciembre de 2005, <www.infor.cl>, 15 março 2008.

Infor (Instituto Forestal de Chile) (2007), “Análisis de la cadena productiva de la celulosa y el papel en países de ALC a la luz de los objetivos de desarrollo sostenible, su relación con los compromisos comerciales (OMC y TLCS) y ambientales (AMUMAS): estudio de caso Chile", <www.infor.cl>, 10 novembro 2007.

Inforsa (Industrias Forestales s.A.) (2008), <www.inforsa.cl>, 18 fevereiro 2008.

Luraschi, Marcos (2007), “Análisis de la cadena productiva de la celulosa y el papel a la luz de los objetivos de desarrollo sostenible: estudio del caso de Chile", <http://www.eclac.org>, 28 março 2008.

Norske Skog (2008), Norske Skog Bio Bio, <www.norskeskog.com/Business-units/South-America/Norske-Skog-Bio-Bio.aspx>, 18 fevereiro 2008.

Parra, Oscar Barrientos, Cláudio Valdovinos Zarges, Evelyn Habit Conejeros y Ricardo Figueroa Jara (2004), "Programa de Monitoreo de la Calidad del Agua del Sistema Río Bío-Bío (рмвв): 19942004", <www.eula.cl>, 19 janeiro 2008.

PNUd (Programa Nacional das Naçóes Unidas para o Desenvolvimento) (2006), "Las Trayectorias del Desarrollo Humano en las Comunas de Chile (1994-2003)", <www.pnud.cl>, 25 março 2008.

PNUD (Programa Nacional das Naçóes Unidas para o Desenvolvimento) (2011), "Human Development Report 2011", <http://hdr.undp. org/en/>, 12 março 2011.

Plaza de los Reyes del Río, Catalina (2008), Informe presentado a la clase de Procesos Productivos y Tecnologías Limpias Aplicado a Recursos Hídricos en junio de 2008. Industria Forestal: Silvicultura y Aserraderos. Este informe foi apresentado como avaliação da disciplina de Processo de Produção Limpa, ministrada pelo 
Dr. Claudio Zaror Zaror do Centro de Ciencias Ambientales da Universidad de Concepción. Documento obtenido junto a alumna de doctorado en Ciencias Ambientales del Centro-eula, Catalina Plaza de los Reyes Del Río.

шв (World Bank) (2011), Chile data, <http://data.worldbank.org/country/chile>, 12 março 2011.

Recibido: 25 de junio de 2009. Reenviado: 14 de marzo de 2011.

Reenviado: 5 de julio de 2011. Aceptado: 13 de septiembre de 2011.

Junior Ruiz-Garcia é mestre em desenvolvimento econômico agrário e agrícola do Instituto de Economia da Universidade Estadual Campinas (Unicamp) da cidade Campinas do Estado de São Paulo, Brasil. Atualmente é doutorando em desenvolvimento econômico espaço e Meio Ambiente do Instituto de Economia da Universidade Estadual Campinas (Unicamp), da cidade Campinas do Estado de São Paulo, Brasil. Bolsista de doutorado do Centro Internacional Celso Furtado. A linha de pesquisa está associada a diversas áreas da economia com destaque, para discussôes sobre a produção de biodiesel no Brasil e questôes associadas á economia ambiental, em especial a vertente teórica conhecida como Economia Ecológica (Ecological Economics). Entre suas publicações destacam-se: "Concentração industrial e regional da produção de biodiesel brasileira", Análise (Jundiai), viII, pp. 49-61 (2008); "O biodiesel no Estado do Paraná: panorama, perspectivas e desafios", VEcopar-Encontro de Economia Paranaense, Curitiba (2007); "Governança da cadeia produtiva do biodiesel”, Revista de Política Agrícola, xviII, pp. 60-79 (2009); "Preço da água e gestão de bacias hidrográficas", Alexandre Bragança Coelho; Erly Cardoso Teixeira; Marcelo José Braga (org.), Recursos Naturais e Crescimento Econômico, Suprema Gráfica e editora, Viçosa, pp. 489-514 (2008); "An Appraisal of a System of Payment of Ecosystem Services in the Brazilian Amazon", The 10th Biennial International Society for Ecological Economis Conference, Nairobi 2008. 